\title{
Ballistic Behavior of New Alumina Composites Reinforced with Niobo-Phosphate Glass
}

\author{
Jheison Lopes dos Santos ${ }^{a, b} * \oplus^{\circ}$, Tiago Jonata de Souza Oliveira ${ }^{a}$, Daniel Navarro da Rocha ${ }^{a, c}$, \\ Camila Cristine Lopes ${ }^{a}$, Marcelo Henrique Prado da Silva ${ }^{a}$ \\ ${ }^{a}$ Instituto Militar de Engenharia - IME, Departamento de Ciência dos Materiais, CEP 22290-270, \\ Rio de Janeiro, RJ, Brasil \\ ${ }^{b}$ Universidade Candido Mendes - UCAM, Rio de Janeiro, RJ, Brasil \\ ${ }^{c} R$-Crio Criogenia S/A, Departamento de Bioengenharia, Campinas, São Paulo, SP, Brasil
}

Received: February 22, 2019; Revised: May 28, 2019; Accepted: June 26, 2019

\begin{abstract}
This work aimed to produce and evaluate the ballistic behavior of niobo-phosphate glass-doped alumina composites. The niobo-phosphate glass $\left(30 \% \mathrm{Nb}_{2} \mathrm{O}_{5}-30 \% \mathrm{P}_{2} \mathrm{O}_{5}-20 \% \mathrm{CaO}-20 \% \mathrm{CaF}_{2}\right.$, by mol $)$ were added to the alumina in six different weight percentages. The composite with the highest densification, measured by the Archimedes assay, was used for the ballistic tests. X-ray diffraction (XRD), scanning electron microscopy (SEM) and X-ray spectroscopy by dispersive energy (EDX) were also performed. The sintered samples were enveloped on two 1020 steel plates for the residual velocity test. The best results of densification were obtained for the niobo-phosphate glass addition of $4 \mathrm{wt} \%$, which was not detected the $\mathrm{AlPO}_{4}$ phase formation. From the residual velocity test, it was observed a better energy absorption for the doped alumina, in relation to pure alumina. Therefore, it is indicated that the niobo-phosphate glass addition of $4 \mathrm{wt} \%$ worked properly as sintering aid for alumina, enhancing its properties and performance.
\end{abstract}

Keywords: $\mathrm{Al}_{2} \mathrm{O}_{3}$, niobo-phosphate glass, sintering, ballistic.

\section{Introduction}

Zirconia, yttria, silicon carbide, boron carbide, and alumina are examples of ceramic materials used for different applications ${ }^{1-6}$. Alumina $\left(\mathrm{Al}_{2} \mathrm{O}_{3}\right)$, even being one of the most important engineering ceramics, has negative characteristics, such as low tensile strength, high brittleness and low toughness ${ }^{7-10}$. Several additives are used as sintering aid in an attempt to optimizing properties. Among these aids, $\mathrm{Nb}_{2} \mathrm{O}_{5}$ (niobium oxide) $)^{11-13}$ is an example of additive for reducing the alumina sintering temperature to $1400-1450{ }^{\circ} \mathrm{C}^{14,15}$.

Another sintering aid used in $\mathrm{Al}_{2} \mathrm{O}_{3}$-based ceramics is LiF (lithium fluoride), as it induces liquid-phase sintering, optimizing the process ${ }^{16-19}$. In a recent study, Santos et al reported good densification of $\mathrm{Al}_{2} \mathrm{O}_{3}-4 \mathrm{wt} \% \mathrm{Nb}_{2} \mathrm{O}_{5}$ ceramics after addition of $0.5 \mathrm{wt} \%$ of $\mathrm{LiF}^{18}$. The use of glasses is also a strategy for fostering liquid-phase sintering.

Due to their high compressive strength and hardness, many ceramic materials are used as the first component in a multilayered armor system. Its main function is to dissipate a significant amount of the projectile energy by means of the fragmentation of the projectile tip as well as by the fragmentation of the ceramic layer ${ }^{14,20-25}$. The second layer, just behind the ceramic, may be either a high strength polymeric fiber, such as aramid, or a high molecular weight polyester, as composed of polymeric matrix composites and fibers.
The function of this intermediate layer is in holding the fragments of the first layer, composed by a fragile material, as well as helping in the energy dissipation of the projectile.

Currently, research efforts have been developed in using natural fibers in polymer matrices, such as curaua ${ }^{26}$, jute ${ }^{27}$, sisal $^{28}$, bamboo $^{29}$ and ramie $^{30}$. All these analyzed fibers presented a good performance as components of a multilayer armor systems.

For high loading rates, the phenomenon occurs more localized. That is, there are regions of the body that have not yet felt the influence of the passage of the waves of tension and deformation. This localized disturbance, caused by dynamic loading, propagates in the solid in the form of a tension wave. In this process, the stresses move through the material with a front delimiting a deformed region of a non-deformed region. The transmission of internal stress is from atom to atom, moving through the body at specific speeds, which can be determined with good approximation. The ballistic behavior of the materials is linked to its dynamic response to high deformation rates. Therefore, the imposed external request can produce elastic, plastic or shock waves as a response ${ }^{31}$.

In the present work, a new alumina-based ceramics were developed for ballistic applications. A niobo-phosphate glass ${ }^{32}$ with molar composition of $30 \mathrm{~mol} \% \mathrm{Nb}_{2} \mathrm{O}_{5}-30 \mathrm{~mol} \% \mathrm{P}_{2} \mathrm{O}_{5}$ $20 \mathrm{~mol} \% \mathrm{CaO}-20 \mathrm{~mol} \% \mathrm{CaF}_{2}$ was added to alumina as a sintering aid, in different fractions: $0,4,8,12,16,20$ and $25 \mathrm{wt} \%$. These composites were characterized with respect to densification, morphology and structure. The residual velocity was assessed by ballistic tests.

*e-mail: lopesjheison@gmail.com 


\section{Materials and Methods}

\subsection{Niobo-phosphate glass production}

A niobo-phosphate glass was prepared with $30 \mathrm{~mol} \%$ of $\mathrm{Nb}_{2} \mathrm{O}_{5}, 30 \mathrm{~mol} \%$ of $\mathrm{P}_{2} \mathrm{O}_{5}, 20 \mathrm{~mol} \%$ of $\mathrm{CaO}$ and $20 \mathrm{~mol} \%$ of $\mathrm{CaF}_{2}$. As precursors were used the ortho-phosphoric acid (Merck, Germany), calcium fluoride (Sigma-Aldrich, EUA), niobium oxide (CBMM, Brazil) and calcium carbonate (Vetec, Brazil). The phosphoric acid was first placed in a becker, which was mixed with calcium fluoride and homogenized. Then, the niobium oxide was added, followed by further homogenization. Finally, calcium carbonate was added to the mixture. The produced material was melted at $1350{ }^{\circ} \mathrm{C}$ for $1 \mathrm{~h}$, and the liquid glass was poured into a second becker, with deionized water for quench process. After this, the glass was sieved (60 mesh) and then placed in a drying oven.

\subsection{Samples preparation}

The precursor ceramic mixture consisted of $94.53 \mathrm{wt} \%$ of alumina (Treibacher Scheifmittel, Brazil), $3.94 \mathrm{wt} \%$ of niobia (CBMM, Brazil) and $1.53 \mathrm{wt} \%$ of polyethylene glycol (PEG) organic binder (Vetec, Brazil). Thereafter, amounts of $0.0 \mathrm{wt} \%, 4.0 \mathrm{wt} \%, 8.0 \mathrm{wt} \%, 12.0 \mathrm{wt} \%, 16.0 \mathrm{wt} \%, 20.0$ $\mathrm{wt} \%$ and $25.0 \mathrm{wt} \%$ were added to the precursor ceramic. The final powders material were comminuted and homogenized in deionized water for $8 \mathrm{~h}$, dried at $70^{\circ} \mathrm{C}$ for $48 \mathrm{~h}$, and then sieved ( 60 mesh). The samples were made by uniaxial cold pressing, at $50 \mathrm{MPa}$, in two matrices: a hexagonal stainless steel matrix, with the surface area of $1.767 \times 10^{-4} \mathrm{~m}^{2}$, for ballistic tests, and a $20 \mathrm{~mm}$ internal diameter cylindrical matrix, for the other characterizations. The sintering of the samples was carried out in a model FE-1700 INTI oven, with the thermal cycle described below:

1) Heating from $25^{\circ} \mathrm{C}$ to $158^{\circ} \mathrm{C}$ at the rate of $1^{\circ} \mathrm{C} / \mathrm{min}$;

2) Plateau at $158^{\circ} \mathrm{C}$ for $1 \mathrm{~h}$;

3) Heating from $158^{\circ} \mathrm{C}$ to $375^{\circ} \mathrm{C}$ at the rate of $1^{\circ} \mathrm{C} / \mathrm{min}$;

4) Heating from $375^{\circ} \mathrm{C}$ to $1000^{\circ} \mathrm{C}$ at the rate of $8^{\circ} \mathrm{C} / \mathrm{min}$;

5) Heating from $1000^{\circ} \mathrm{C}$ to the final sintering temperature $\left(1500^{\circ} \mathrm{C}\right)$ at the rate of $3{ }^{\circ} \mathrm{C} / \mathrm{min}$;

6) Sintering plateau at $1500{ }^{\circ} \mathrm{C}$ for $1 \mathrm{~h}$.

7) Cooling at a rate of $3{ }^{\circ} \mathrm{C} / \mathrm{min}$ to $700^{\circ} \mathrm{C}$, when the oven was shut down and cooled by its own inertia.

\subsection{Characterizations}

After sintering, the samples were submitted to the Archimedes test, in accordance with ABNT NBR 6220, in order to determinate the apparent density and then densification based on the theoretical density. The analysis of the formed phases was obtained by the X-ray diffraction technique. It was performed at room temperature in a model X'Pert Pro Panalytical diffractometer.
The operation occurred with a voltage of $45 \mathrm{kV}$ and electric current of $40 \mathrm{~mA}$, in the range $10^{\circ}<2 \theta<80^{\circ}$, with a step size of $0.02^{\circ}, \mathrm{Cu}_{\mathrm{K} \alpha}$ radiation, and collection time of $2 \mathrm{~s}$. For the morphology and chemical composition characterizations, a model JSM-5800LV JEOL scanning electron microscope was used, with voltage of 10 and $30 \mathrm{kV}$. Deposition of platinum was carried out in order to favor the analysis.

\subsection{Ballistic tests}

The densification has an important role in the dynamic behavior of the materials ${ }^{19,22,23}$. Thus, the composition that presented the highest densification value by the Archimedes test was selected for the ballistic tests. The sintered hexagonal samples, of $3.8 \mathrm{~cm}$ edge, almost $100 \mathrm{~g}$ of mass and $10 \mathrm{~mm}$ thick, were attached on 1020 steel plates $(15 \mathrm{~cm} \mathrm{x} 15 \mathrm{~cm}$, and $5 \mathrm{~mm}$ thick) so that the specimens were enveloped. The fixation of these plates to the specimens was done with a polyurethane adhesive. As the reference, the plates were also tested without the ceramic samples, in order to verify the effect of only the spaced metal plates. The residual velocity test was performed at the Brazilian Army Assessment Center. For the test, it was used a $7.62 \times 51 \mathrm{~mm}$ projectile, with a mass of $9.4876 \mathrm{~g}$, fired at a distance of $15 \mathrm{~m}$ from the target. The projectile's velocities before and after the impact were measured by SL-52 OP Weibel fixed-head Doppler radar system. The fixation of the encapsulated specimens is shown in Figure 1.

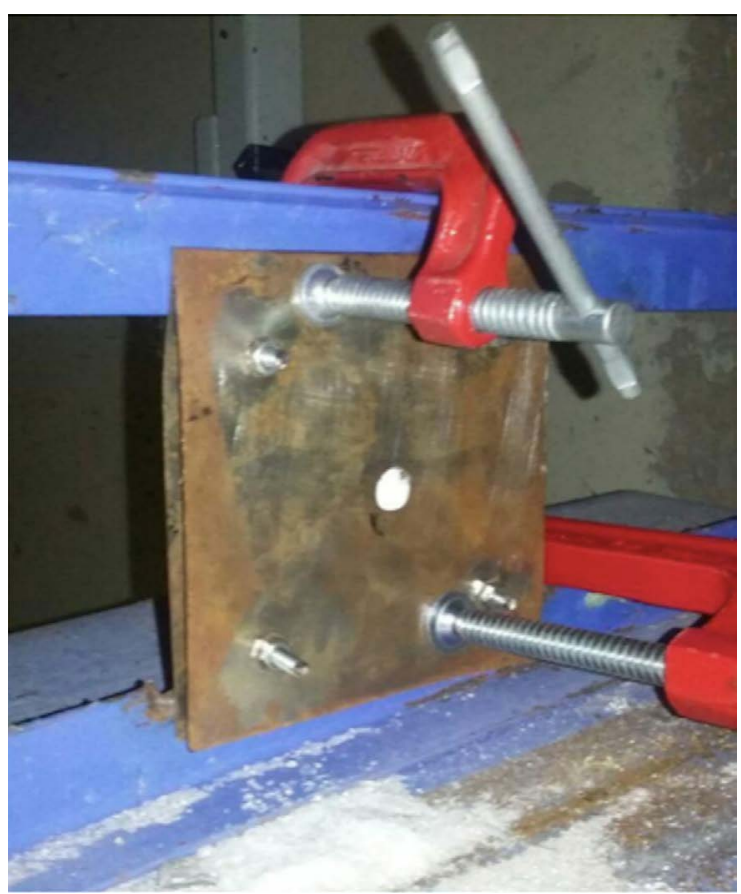

Figure 1. Fixing of samples confined by the steel plates for the ballistic tests. 


\section{Results and Discussion}

\subsection{Density and densification}

The results of density and densification for the sintered samples are presented in Table 1. The pure alumina presented the lowest values of densification, associated with the low temperature adopted for the sintering process ${ }^{15,18}$. Besides that, one can observe that all the additions yielded in densifications values higher than pure alumina, with the highlight for the $4 \mathrm{wt} \%$ fraction. Such content achieved about $90.48 \%$ of densification, as a consequence of the glass melting, promoting the liquid phase sintering ${ }^{15,18}$. Therefore, this was the selected addition to be dynamically evaluated in the ballistic tests.

\section{$3.2 X$-ray diffraction}

The results of the X-ray diffraction of the sintered samples are shown in Figure 2. The identified phases were corundum $\left(\mathrm{Al}_{2} \mathrm{O}_{3}-\mathrm{JCPDS}\right.$ 00-046-1212), fluorite $\left(\mathrm{CaF}_{2}-\right.$ JCPDS 00-035-0816), calcium niobate $\left(\mathrm{CaNb}_{2} \mathrm{O}_{6}-\mathrm{JCPDS}\right.$ 00-039-1392) and aluminum phosphate, $\left(\mathrm{AlPO}_{4}-\mathrm{JCPDS}\right.$ 00-031-0028), in the samples with the percentage of niobophosphate glass different from zero. Table 2 presents a resume of the crystalline phases detected. The quantitative phase determination was carried out by the Rietveld method, using TOPAS Academic version 4.1 software, based on the statistical indicators $\left(\mathrm{R}_{\mathrm{wP}}\right.$ and GOF) best results.

It can be seen that for the $4 \mathrm{wt} \%$ of niobo-phosphate glass addition, the aluminum phosphate phase was not detected. It was also observed that the percentage of $\mathrm{CaF}_{2}$ decreased with the reduction of the niobo-phosphate glass content.

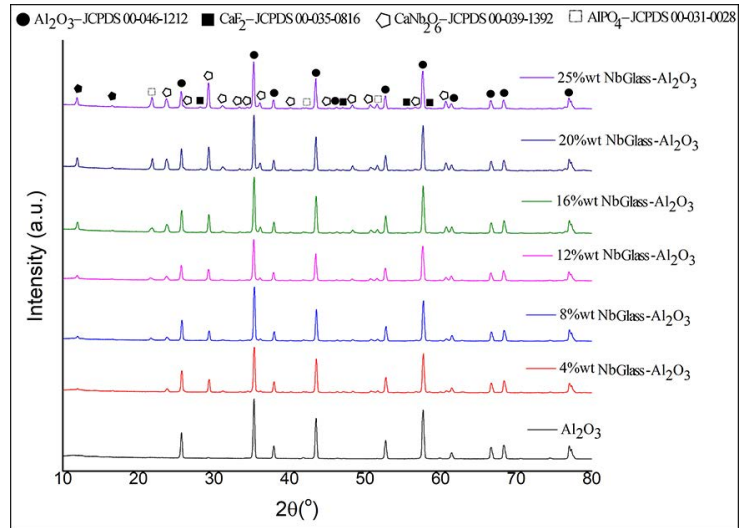

Figure 2. XRD results of the sintered samples.

The sample with $4 \mathrm{wt} \%$ of niobo-phosphate glass was the one with the lowest content of $\mathrm{CaF}_{2}$ and did not presented the $\mathrm{AlPO}_{4}$ phase. Chao et al. ${ }^{33}$ indicated that $\mathrm{AlPO}_{4}$ presents sintering difficulties above $1000^{\circ} \mathrm{C}$, and also its use as weak interphase material in ceramic-matrix composites. Therefore, as the sample with $4 \mathrm{wt} \%$ niobo-phosphate glass was the one with the best densification, these phases are likely to interfere with the alumina densification, more precisely $\mathrm{CaF}_{2}$ and $\mathrm{AlPO}_{4}$.

\subsection{Morphological and Chemical Analyses}

Figure 3 shows the different morphologies between the fracture surfaces of pure alumina and niobo-phosphate niobo-phosphate glass-doped alumina samples. As expected, for thermal treatment at $1500{ }^{\circ} \mathrm{C}$, the sintering did not occur completely for the pure alumina samples, Figure 3(a).

Table 1. Values of density and densification of the sintered samples.

\begin{tabular}{ccc}
\hline Glass addition (wt.\%) & Density $\left(\mathbf{g} / \mathbf{c m}^{3}\right)$ & Densification $\mathbf{( \% )}$ \\
\hline 0.0 & $3.56 \pm 0.01$ & $65.24 \pm 0.59$ \\
4.0 & $3.97 \pm 0.01$ & $90.49 \pm 0.60$ \\
8.0 & $3.95 \pm 0.01$ & $88.38 \pm 0.21$ \\
12.0 & $3.35 \pm 0.01$ & $87.90 \pm 0.74$ \\
16.0 & $3.93 \pm 0.01$ & $83.06 \pm 1.02$ \\
20.0 & $3.89 \pm 0.01$ & $81.31 \pm 1.21$ \\
25.0 & $3.90 \pm 0.01$ & $76.15 \pm 1.41$ \\
\hline
\end{tabular}

Table 2. Percentage of crystalline structures, according to the glass addition.

\begin{tabular}{ccccc}
\hline Glass addition (wt.\%) & $\mathrm{Al}_{2} \mathrm{O}_{3}(\%)$ & $\mathrm{CaF}_{2}(\%)$ & $\mathrm{CaNb}_{2} \mathrm{O}_{6}$ & $\mathrm{AlPO}_{4}$ \\
\hline 0.0 & 100 & 0 & 0 & 0 \\
4.0 & 95.41 & 0.14 & 4.45 & 0 \\
8.0 & 94.01 & 0.61 & 3.86 & 1.51 \\
12.0 & 91.73 & 0.55 & 5.58 & 2.13 \\
16.0 & 89.66 & 0.64 & 7.06 & 2.64 \\
20.0 & 86.19 & 0.82 & 9.68 & 3.32 \\
25.0 & 83.66 & 0.90 & 10.43 & 5.01 \\
\hline
\end{tabular}



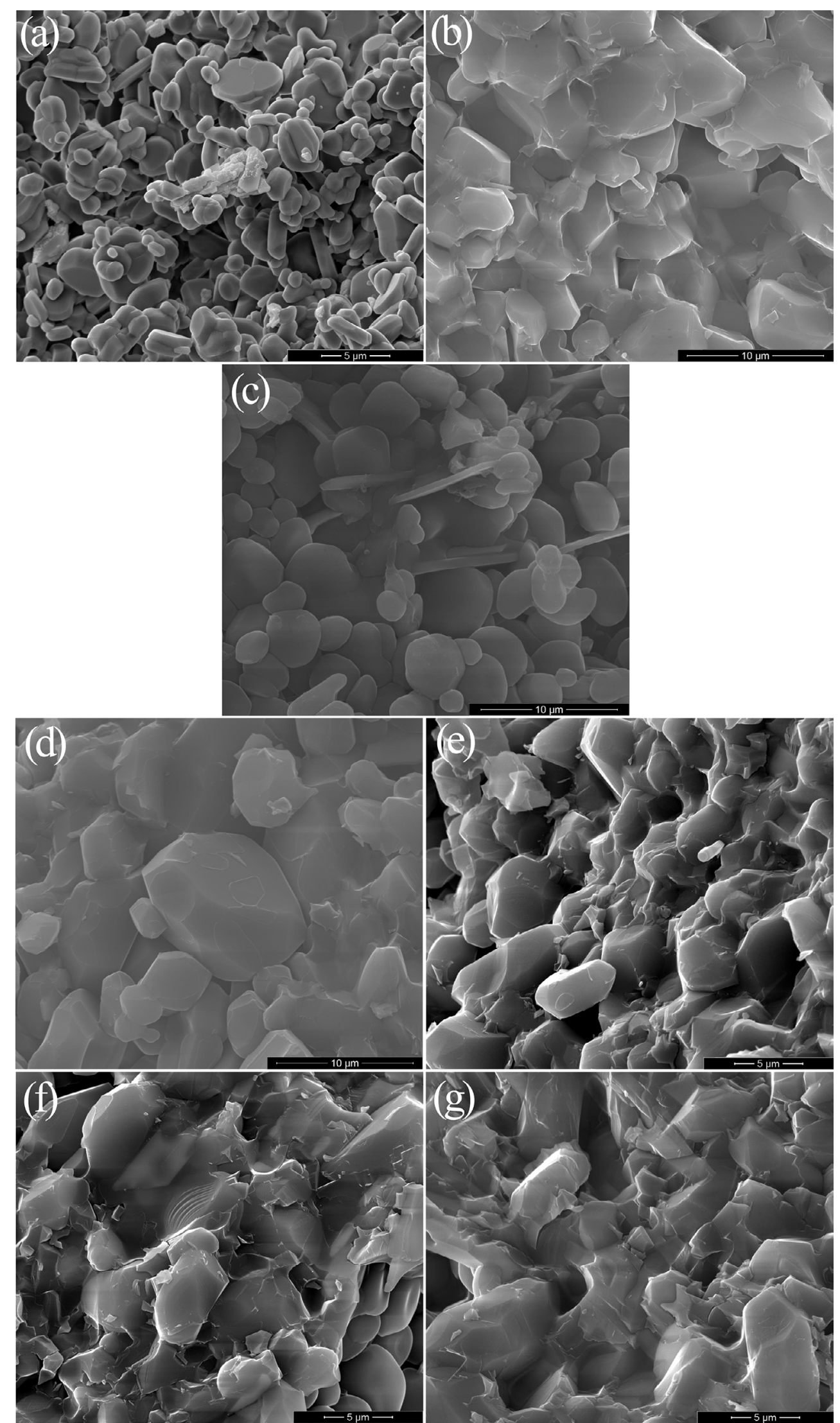

Figure 3. Morphological aspects of the samples with (a) $0 \mathrm{wt} \%$, (b) $4 \mathrm{wt} \%$, (c) $8 \mathrm{wt} \%$, (d) $12 \mathrm{wt} \%$, (e) $16 \mathrm{wt} \%$, (f) $20 \mathrm{wt} \%$ and (g) $25 \mathrm{wt} \%$ niobo-phosphate glass additions. 
It is possible to observe the granules in the initial stage of sintering, with only tangential contact, while it is also noted the presence of granules in the process of coalescence, indicating the incomplete sintering process.

On the contrary, Figure 3(b) shows the complete sintering process for the $4 \mathrm{wt} \%$ of niobo-phosphate niobo-phosphate glass addition, exhibiting the three stages of sintering. The morphology of the round shaped grains was changed to faceted grains. In addition, the presence of the niobo-phosphate glass provided a certain wettability aspect at grain boundaries, due to the sintering in the presence of a liquid phase. The wettability is responsible for the better compaction and accommodation of the grains, allowing a more cohesive structure and better densification of the samples, compared to the pure alumina.

In Figure 3(c), the samples with $8 \mathrm{wt} \%$ niobo-phosphate glass content in alumina demonstrated irregular sintering, with the formation of flakes in some regions. In other regions, it can be seen the presence of both faceted grains and not coalesced round shaped grains. For these two regions, no differences in composition were found by EDS analysis.

Similar morphological aspects are observed in the samples $12 \mathrm{wt} \%, 16 \mathrm{wt} \%$ and $20 \mathrm{wt} \%$, Figure 3 (d-f) exhibiting the faceted crystals and the sintering in the presence of liquid phase. Furthermore, it is not possible to delimit the limits of some grains in the $16 \mathrm{wt} \%$ and 20 $w t \%$ of niobo-phosphate glass addition, due to the increase of the glass content is followed by the greater wettability of the grain boundaries.

For $25 \mathrm{wt} \%$ of glass content, Figure $3(\mathrm{~g})$, it is observed a completely different morphological aspect in comparison with the pure alumina sample. The grains present a completely faceted aspect, suggesting greater sintering in the presence of liquid phase. However, as can be seen in Table 1, lower efficient densification was verified, when compared with the previous samples. The higher value for densification, calculated experimentally, occurred in the $4 \mathrm{wt} \%$ niobophosphate glass-doped alumina.

\subsection{Ballistic tests}

Table 3 shows the mean values and standard deviation of the velocities before and after the impact, as well as the values of absorbed energy by the ballistic armor, calculated by the difference between the projectile's kinetic energy prior and after the impact, relative to the kinetic energy before the impact. The mass was assumed to be constant.

It can be observed that the specimens with a percentage of $4 \mathrm{wt} \%$ of niobo-phosphate glass dissipated a much more significant percentage $(76.2 \%)$ than the specimens with pure alumina $(43.6 \%)$. It represents a relative increase of about $75 \%$ with the niobo-phosphate glass additivation. This is due to the better densification of the specimens with a $4 \mathrm{wt} \%$ of niobo-phosphate glass and its consequent greater efficiency in eroding the tip of the projectile ${ }^{14,19,22,23,31}$. Besides that, it can also be seen that the steel plates represent a non-significant percentage of energy dissipation, around $3.4 \%$.

Figure 4(a) shows one of the shots on the specimen with pure alumina, and Figure 4(b) corresponds to one of the shots in the specimen with addition of $4 \mathrm{wt} \%$ niobo-phosphate glass. The presence of confined pure alumina ceramic fragments is observed. On the other hand, no fragments of the doped alumina were found. Therefore, the greatest dissipation of energy by alumina specimens with $4 \mathrm{wt} \%$ of niobo-phosphate glass was visualized, since such ceramic component was pulverized, corroborating the results of Table $3^{31}$.
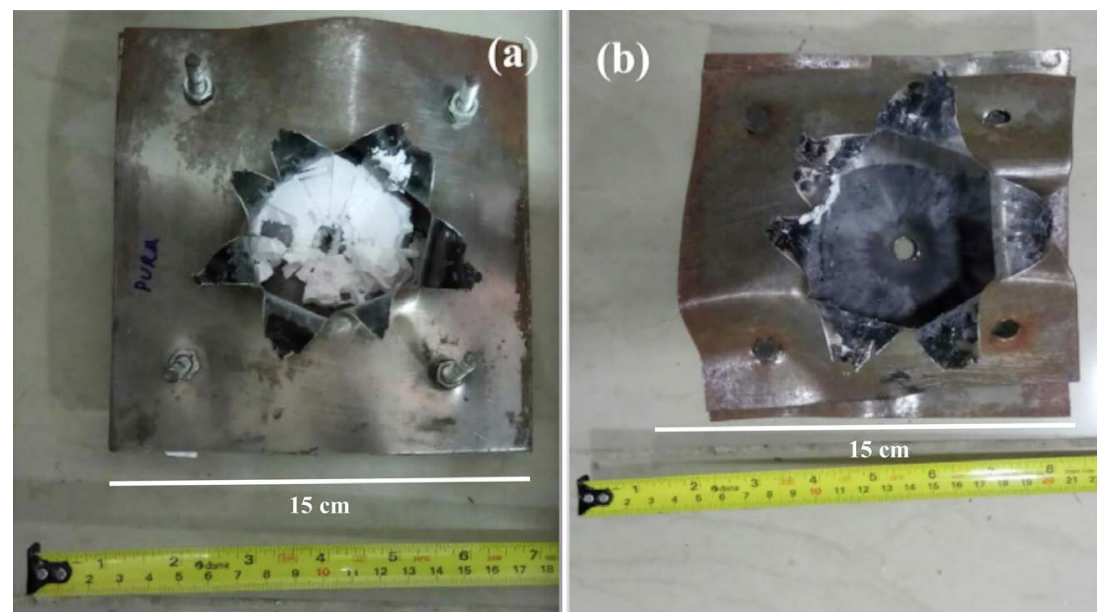

Figure 4. Samples of (a) pure alumina and (b) niobo-phosphate glass-doped alumina after ballistic impact.

Table 3. Results of residual velocity and absorbed energy from the ballistic tests.

\begin{tabular}{cccc}
\hline Samples & Vel. before the impact (m/s) & Vel. after the impact (m/s) & Absorbed Energy (\%) \\
\hline Blank & $769.4 \pm 11.4$ & $756.2 \pm 10.0$ & $3.4 \pm 0.2$ \\
Pure alumina & $806.5 \pm 5.0$ & $605.7 \pm 27.8$ & $43.6 \pm 5.4$ \\
$\mathrm{Al}_{2} \mathrm{O}_{3}+4$ wt.\% glass & $805.2 \pm 13.9$ & $393.2 \pm 30.3$ & $76.2 \pm 4.3$ \\
\hline
\end{tabular}




\section{Conclusions}

The results of the Archimedes test showed that the addition of $4 \mathrm{wt} \%$ of the niobo-phosphate glass to alumina exhibited the highest densification value after sintering. This composition also presented high linear retraction. According to the XRD results, it is suggested that the absence of the $\mathrm{AlPO}_{4}$ fostered the sintering process, and thus the densification.

By scanning electron microscopy analysis, it was possible to notice that the samples of alumina with several percentages of niobo-phosphate glass presented both faceted and rounded grains, due to liquid-phase sintering, provided by the glass melting.

Samples of alumina with $4 \mathrm{wt} \%$ of glass showed a $75 \%$ higher performance as a ballistic armor than that of pure alumina samples. For the composite samples, the projectile's energy showed a reduction of $76.2 \%$ of the total kinetic energy, while pure alumina samples showeda reduction of $43.6 \%$ in the total kinetic energy of the projectile.

\section{References}

1. Aragón-Duarte MC, Nevarez-Rascón A, Esparza-Ponce HE, Nevarez-Rascón MM, Talamantes RP, Ornelas C, et al. Nanomechanical properties of zirconia- yttria and alumina zirconia-yttria biomedical ceramics, subjected to low-temperature aging. Ceramics International. 2017;43(5):3931-3939.

2. Guo WM, Zhang ZL, Li JX, You Y, Wu SH, Lin HT. Improvement of densification and mechanical properties of $\mathrm{Al}_{2} \mathrm{O}_{3}-\mathrm{B}_{4} \mathrm{C}$ ceramics. Ceramics International. 2016;42(9):11486-11489.

3.Maity A, Kayal N, Chakrabarti O. Mechanical behaviour of reaction processed $\mathrm{SiC}$ ceramics from artificial precursor from plant. Ceramics International. 2016;42(8):10058-10065.

4. Li B, Xu Y, Zhang S. The size-effect of $\mathrm{Al}_{2} \mathrm{O}_{3}$ on the sinterability, microstructure and properties of glass-alumina composites. Glass Physics and Chemistry. 2015;41(5):503-508.

5.Lü Z, Jiang D, Zhang J, Lin Q, Huang Z. ZrB - -SiC laminated ceramic composites. Journal of the European Ceramic Society. 2012;32(7):1435-1439.

6. Zhang XY, Wu JM, Yang JL. Pore morphology designs of porous $\mathrm{Si}_{3} \mathrm{~N}_{4}$-based ceramics using $\mathrm{Si}_{3} \mathrm{~N}_{4}$ and $\mathrm{Al}_{2} \mathrm{O}_{3}$ poly-hollow microspheres as pore-forming agents. Materials Letters. $2015 ; 144: 39-42$

7. Zang W, Guo F, Liu J, Du H, Hou F, Guo A. Lightweight alumina based fibrous ceramics with different high temperature binder. Ceramics International. 2016;42(8):10310-10316.

8.Hassan AM, Awaad M, Bondioli F, Naga SM. Densification Behavior and Mechanical Properties of Niobium-Oxide-Doped Alumina Ceramics. Journal of Ceramic Science and Technology. 2014;5(1):51-56.

9.Liu Y, Min F, Zhu J, Zhang M. Effect of nanometer $\mathrm{Al}_{2} \mathrm{O}_{3}$ powder on microstructure and properties of alumina ceramics by microwave sintering. Materials Science and Engineering: $A$. 2012;546:328-331.
10. Zhu B, Zhu Y, Li X, Zhao F. Effect of ceramic bonding phases on the thermo-mechanical properties of $\mathrm{Al}_{2} \mathrm{O}_{3}-\mathrm{C}$ refractories. Ceramics International. 2013;39(6):6069-6076.

11. Nogueira FGE, Ascencios YJO, Rodella CB, Porto ALM, Assaf EM. Alternative route for the synthesis of high surfacearea $\eta-\mathrm{Al}_{2} \mathrm{O}_{3} / \mathrm{Nb}_{2} \mathrm{O}_{5}$ catalyst from aluminum waste. Materials Chemistry and Physics. 2016;184:23-30.

12. Oliveira LNL, Campos RVB, Gouveia DX, Silva MAS, Sombra ASB. Microwave dielectric properties study of $\left(\mathrm{Al}_{2} \mathrm{O}_{3}\right)-\left(\mathrm{Nb}_{2} \mathrm{O}_{5}\right)$ composite for dielectric resonator antenna applications. Microwave and Optical Technology Letters. 2016;58(6):1473-1479.

13.Jang JH, Kim TY, Kim NJ, Lee CH, Park EM, Park C, et al. Preparation and characterization of $\mathrm{Nb}_{2} \mathrm{O}_{5}-\mathrm{Al}_{2} \mathrm{O}_{3}$ composite oxide formed by cathodic electroplating and anodizing. Materials Science and Engineering: B. 2011;176(18):1505-1508.

14. Gomes AV, Louro LHL, Costa CRC. Ballistic behavior of alumina with niobia additions. Journal de Physique IV. 2006;134:1009-1014.

15.Trindade W, da Silva MHP, Gomes AV, de Campos JB, Louro LHL. Processing and Properties of Niobia-Doped Alumina Sintered at $1400^{\circ}$ C. Materials Science Forum. 2014;798-799:665-670.

16. Sutorik AC, Cooper C, Gilde G. Visible Light Transparency for Polycrystalline Ceramics of $\mathrm{MgO}-2 \mathrm{Al}_{2} \mathrm{O}_{3}$ and $\mathrm{MgO}-2.5 \mathrm{Al}_{2} \mathrm{O}_{3}$ Spinel Solid Solutions. Journal of the American Ceramic Society. 2013;96(12):3704-3707.

17. Sutorik AC, Gilde G, Cooper C, Wright J, Hilton C. The Effect of Varied Amounts of LiF Sintering Aid on the Transparency of Alumina Rich Spinel Ceramic with the Composition $\mathrm{MgO} \cdot 1.5 \mathrm{Al}_{2} \mathrm{O}_{3}$. Journal of the American Ceramic Society. 2012;95(6):1807-1810.

18. Santos JL, Marçal RLSB, Jesus PRR, Gomes AV, Lima Jr EP, Monteiro SN, et al. Effect of LiF as Sintering Agent on the Densification and Phase Formation in $\mathrm{Al}_{2} \mathrm{O}_{3}-4 \mathrm{wt} \% \mathrm{Nb}_{2} \mathrm{O}_{5}$ Ceramic Compound. Metallurgical and Materials Transactions A. 2017;48(10):4432-4440.

19. dos Santos JL, Marçal RLSB, de Jesus PRR, Gomes AV, Lima Jr EP, da Rocha DN, et al. Mechanical properties and ballistic behavior of $\mathrm{LiF}$-added $\mathrm{Al}_{2} \mathrm{O}_{3}-4 \mathrm{wt} \% \mathrm{Nb}_{2} \mathrm{O}_{5}$ ceramics. Journal of Materials Research and Technology. 2018;7(4):592-597.

20. Chen M, McCauley JW, Hemker KJ. Shock Induced Localized Amorphization in Boron Carbide. Science. 2003;299(5612):15631566.

21. Walley SM. Historical review of high strain rate and shock properties of ceramics relevant to their application in armour. Advances in Applied Ceramics. 2010;109(8):446-466.

22. Medvedovski E. Ballistic performance of armour ceramics: Influence of design and structure. Part 1. Ceramics International. 2010;36(7):2103-2115

23. da Silva MV, Sainer D, Al-Qureshi HA, Hotza D. Blindagens cerâmicas para aplicações balísticas: uma revisão. Cerâmica. 2014;60(355):323-331.

24. Jiusti J, Kammer EH, Neckel L, Lóh NJ, Trindade W, Silva AO, et al. Ballistic performance of $\mathrm{Al}_{2} \mathrm{O}_{3}$ mosaic armors with gapfilling materials. Ceramics International. 2017;43(2):2697-2704. 
25. Monteiro SN, Louro LHL, Gomes AV, Chagas CFM, Caldeira $\mathrm{AB}$, Lima Jr EP. How effective is a convex $\mathrm{Al}_{2} \mathrm{O}_{3}-\mathrm{Nb}_{2} \mathrm{O}_{5}$ ceramic armor? Ceramics International. 2016;42(6):7844-7847.

26. Monteiro SN, Louro LHL, Trindade W, Elias CN, Ferreira CL, Lima ES, et al. Natural Cuarua Fiber-Reinforced Composites in Multilayered Ballistic Armor. Metallurgical and Materials Transactions A. 2015;46(10):4567-4577.

27. da Luz FS, Lima Junior EP, Louro LHL, Monteiro SN. Ballistic Test of Multilayered Armor with Intermediate Epoxy Composite Reinforced with Jute Fabric. Materials Research. 2015;18(Suppl 2):170-177.

28. Rohen LA, Margem FM, Monteiro SN, Vieira CMF, Araujo BM, Lima ES. Ballistic Efficiency of an Individual Epoxy Composite Reinforced with Sisal Fibers in Multilayered Armor. Materials Research. 2015;18(Suppl 2):55-62.
29. da Cruz RB, Lima Junior EP, Monteiro SN, Louro LHL. Giant Bamboo Fiber Reinforced Epoxy Composite in Multilayered Ballistic Armor. Materials Research. 2015;18(Suppl 2):70-75.

30. Monteiro SN, Milanezi TL, Louro LHL, Lima Jr EP, Braga FO, Gomes AV, et al. Novel ballistic ramie fabric composite competing with Kevlar ${ }^{\mathrm{TM}}$ fabric in multilayered armor. Materials \& Design. 2016;96:263-269.

31. Meyers MA. Dynamic Behavior of Materials. New York: John Wiley \& Sons; 1994.

32. da Silva MHP, Moura Ramirez C, Granjeiro JM, Rossi AM. In Vitro Assessment of New Niobium Phosphate Glasses and Glass Ceramics. Key Engineering Materials. 2008;361-363:229-232.

33. Chen C, Feng B, Hu S, Zhang Y, Li S, Gao L, et al. Control of aluminum phosphate coating on mullite fibers by surface modification with polyethylenimine. Ceramics International. 2018;44(1):216-224. 